\title{
Changes and Exploration of Railway Construction Management under New Situation
}

\author{
Shu-Yu Wang ${ }^{1, a}$, Ying-Ying Wang ${ }^{1, b}$ \\ ${ }^{1}$ Shijiazhuang Tiedao University, Shijiazhuang 050043 \\ awangshuyu888@126.com, b383070092@qq.com
}

\begin{abstract}
Keywords: Railway construction, Government-corporation separation, Management change, Project governance.
\end{abstract}

\begin{abstract}
Research purposes: Under the background of Government-corporation separation, new situation and impact on railway construction management will be discussed. Thus some suggestions will be pointed about how to change management style for National Railway Administration and China Railway Corporation.

Research conclusions: (1) Separation work of government and corporation almost done. China Railway Corporation still has authority managing specific railway construction projects. Ministry of Railway will in charge of Regulations and Standard, and execute Quality, Safety, Market management;(2)Based on the function of National Railway Administration, multi-objective implementation ability shall be raised for the strengthen management of Quality and Safety supervision. In other hand, China Railway Corporation will lose the identity of Government and advantage of coordination but just as a company. As a result, it will be harder to carry forward the progress of railway construction;(3)Thus at this changing period, some suggestions were carry out: National Railway Administration should enhance the concept of law and responsibility. Project manager should change the management style and give more attention for market and contract, in order to realize the project governance not only project management;(4)The research result can be applied in Construction Management field and can be reference for construction management reformation of National Railway Administration and China Railway Corporation.

In March 2013, the original Ministry of Railways was abolished. According to "the State Council Organization Reform and Function Transformation Plan", National Railway Administration and China Railway Corporation were created. But until 2014, National Railway Administration was already established. Thus separation work of government and corporation can be work done officially. Based on the background of government-corporation separation, we will focus on the transformation problem of railway construction management under the new situation.
\end{abstract}

\section{Government-corporation separation and impact}

\section{Government-corporation separation}

Official reply of the State Council on the Organization of China Railway Corporation (the State letter (2013), 47th) clearly stated: China Railway Corporation is mainly engaged in railway passenger and freight transportation services and the implementation of Diversified Business. First, it is responsible for rail transport which unified command and management of the national rail passenger and freight transport. And China Railway Corporation to assume the state's nonprofit transportation, to ensure the livelihood of priority transport, special transport, disaster relief and other transport tasks. Second, it is responsible for the preparation of railway investment and construction plans, proposed national railway network construction and financing program recommendations. Furthermore, it is also responsible for the construction project preparatory work and the management of construction projects. Finally, it is responsible for the national railway transportation safety and production of railway safety.

Through the above description we can see, China Railway Corporation charge for the entire process of project management functions: the contents of railway investment and construction plans, construction project preparatory work, management of construction projects. As we know, China 
Railway Corporation mainly charges for railway operational functions. So China Railway Corporation actually still has railway investment, financing, construction and operation of the whole industry chain function.

According to the internal institutional arrangements of National Railway Administration, the Technology and Legal Division is responsible for technical standards, Project Supervision and Management Division is responsible for the supervision and management of specific projects. Project Supervision and Management Division has been established and started to work, which consists of three departments, namely, comprehensive department, quality and safety supervision department and market supervision department. Its main functions include engineering quality and safety supervision, market supervision and management. Of course, the rights to make the railway construction industry regulations and other regulatory documents are also attributable to National Railway Administration.

\section{Separating effect on the management of railway construction}

Separating effect on railway construction management mainly include two aspects: one aspect is to strengthen the quality, safety and other government regulatory functions, and the other aspect is the China Railway Corporation turn into a weakening external coordination advantages. The former show that the project multi-objective controlling capabilities will be enhanced and the latter show that the negotiating capacity will decrease and coordination costs will increase.

Enhanced ability to multi-objective control of railway construction projects. Projects in the construction process have multiple binding targets, including investment, schedule, quality, safety and environment factors. The establishment of National Railway Administration significantly enhanced control ability of quality and safety functions. Compared to the original situation, multi-objective single control system changed as double control system, which means the Railway Corporation, will charge for internal supervision and the National Railway charge for external control. Thus it will certainly enhance the ability of multi-objective control in railway construction projects. From the organizational point of view, the original railway engineering quality and safe ty supervision team remains in the China Railway Corporation. National Railway Administration will set up seven regional authority and one project quality supervision center to implement engineering supervision function. This will significantly enhance the quality and safety supervision and management strength, and thus enhance the overall level of multi-objective control system. Specifically, as shown in Figure 1.

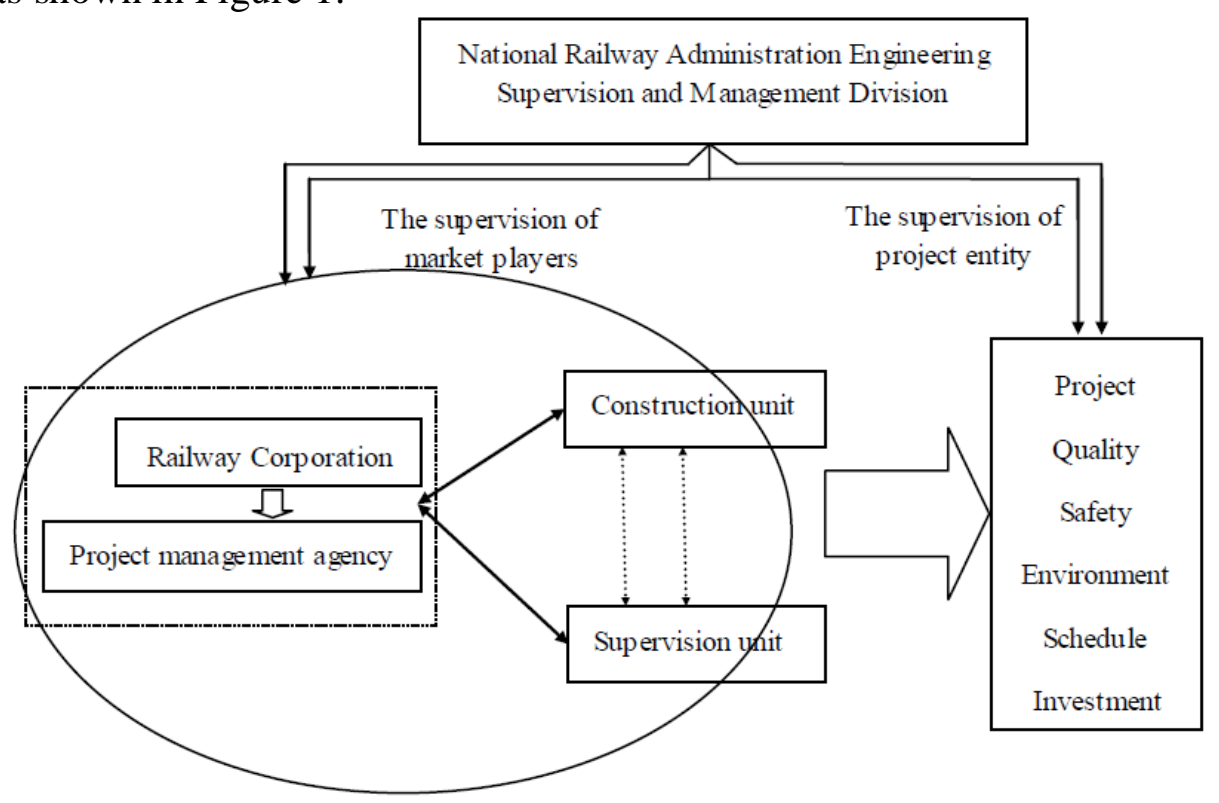

Fig.1 Schematic of railway engineering supervision and management after separating

From the perspective of the subsystem of railway construction goals, the quality and safety 
control capabilities strengthening will also drive pressure on investment and time goals. This means that strengthen the capabilities of the quality and safety supervision will inevitably lead to higher demands on investment and reasonable schedule. It also requires managers devote more energy and establish the related achievement goals scientifically in the pre-construction project, more human and resources inputs in the process of project construction.

More difficulty in Railway construction implementation. Because the change of identity, China Railway Corporation has become the project owner and also lost government's identity and functions. It can no longer use administrative means to promote the project construction and implementation, which affects many aspects of railway construction. For instance, the mechanisms of cooperation with local government, demolition work, and other external coordination work and so on.

In the market-oriented environment, the railway builders who work merely with the owners identity is a new challenge. Specifically mainly in three aspects : First, owners to communicate and coordinate with all levels of government; Second, owners to communicate and coordinate with participation enterprise; Third, owners to communicate and coordinate with projects involving nearby residents. If the railway builders can not adapt to the new changes, the increasingly complex relationship between railway department and local government, land rights and interests dispute and so on, will become important factors that hinder the rapid development of railway construction.

\section{Adjustment of railway construction regulations and rules}

Currently, the railway construction is faced with another change that is the legal system and regulatory adjustments. Although the laws and administrative regulations do not need to be adjusted, just the railway industry department rules and regulatory documents, only Railway Corporation internal regulations and rules are changed. But precisely these parts of the file changes have significant impacts on the railway construction market and the implementation of projects.

\section{Laws and regulations system adjustment}

Before the National Railway Administration officially promulgated the railway industry regulations, the original Ministry of Railways' documents still are valid. For example, No. 11 orders by original Ministry of Railways "Railway Construction Management Approach", No. 25 orders by original Ministry of Railways "Railway Construction Quality Management Regulations" and so on. Specifically, as shown in Figure 2.

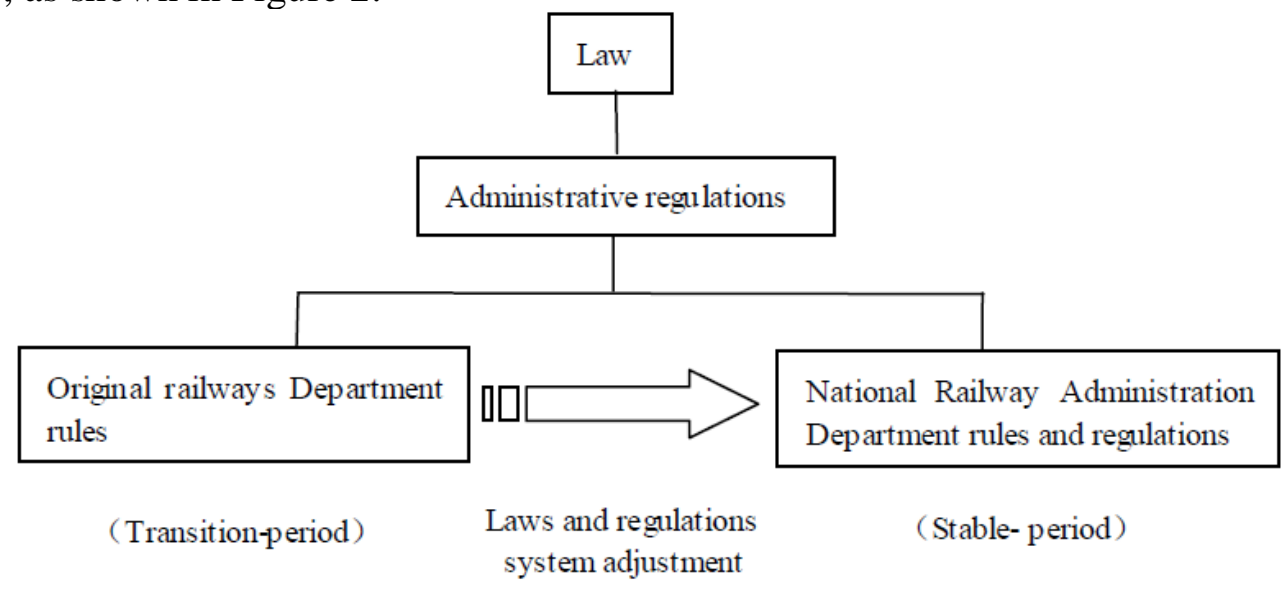

Fig.2 Adjustment of the railway construction sector regulations schematic

So the whole industry is still implementing regulations and requirements that have not been explicitly abolished. According to the National Railway Administration Engineering Supervision and Management division 'responsibilities: the railway construction market, bidding, quality management, safety management and other fields, some new regulations will be developed, which will be used to regulate the entire railway construction market. This part of content does not change 
the existing institutional framework, but government supervision organizations and regulatory approaches will inevitably change legal responsibilities and obligations of the different participation firms may also be a subtle change. Especially, after the start of executing "Railway Safety Management Regulations" in 2014 by State Government, it will put forward higher requirements in terms of quality and safety management.

\section{Rules and regulations adjustment}

In keeping with the requirements of national laws and regulations, the Railway Corporation needs to develop enterprise rules and regulations file in accordance with the actual situation of the enterprise management. These files are used to clear the internal division of management functions and management requirements in railway construction project, but also to strengthen the management functions of subordinate enterprises, such as so many construction management agencies. The specific content of the rules and regulations of the Railway Corporation as shown in Figure 3. While the enterprise rules and regulations adjustment does not belong to the industry management content, but because of the identity of the special project owners, almost all railway construction projects implemented by the Railway Corporation. Therefore, the adjustment and improvement of the Railway Corporation rules and regulations will inevitably lead to change in the project implementation phase.

From the current situation, the Railway Corporation only changed from the original government to corporate identity, its construction management philosophy, construction management team and construction management requirements have not significantly changed. Therefore, the Railway Corporation rules and regulations adjustment focuses on eliminating the original part of government functions, reinforcing the review of enterprise management content, but it does not change the project implementation processes and procedures.

In the short term, the railway construction project rules will not have too big change since the separation; there will still be work within the framework of the original railway construction management. In the long term, with further adjustment of the national railway administration departmental rules and the railway industry, the railway corporation internal rules and regulations will be changed accordingly. Whatever, on the basis of a clear identity, the adjustment of laws system and the regulations will benefit the development of the whole construction industry.

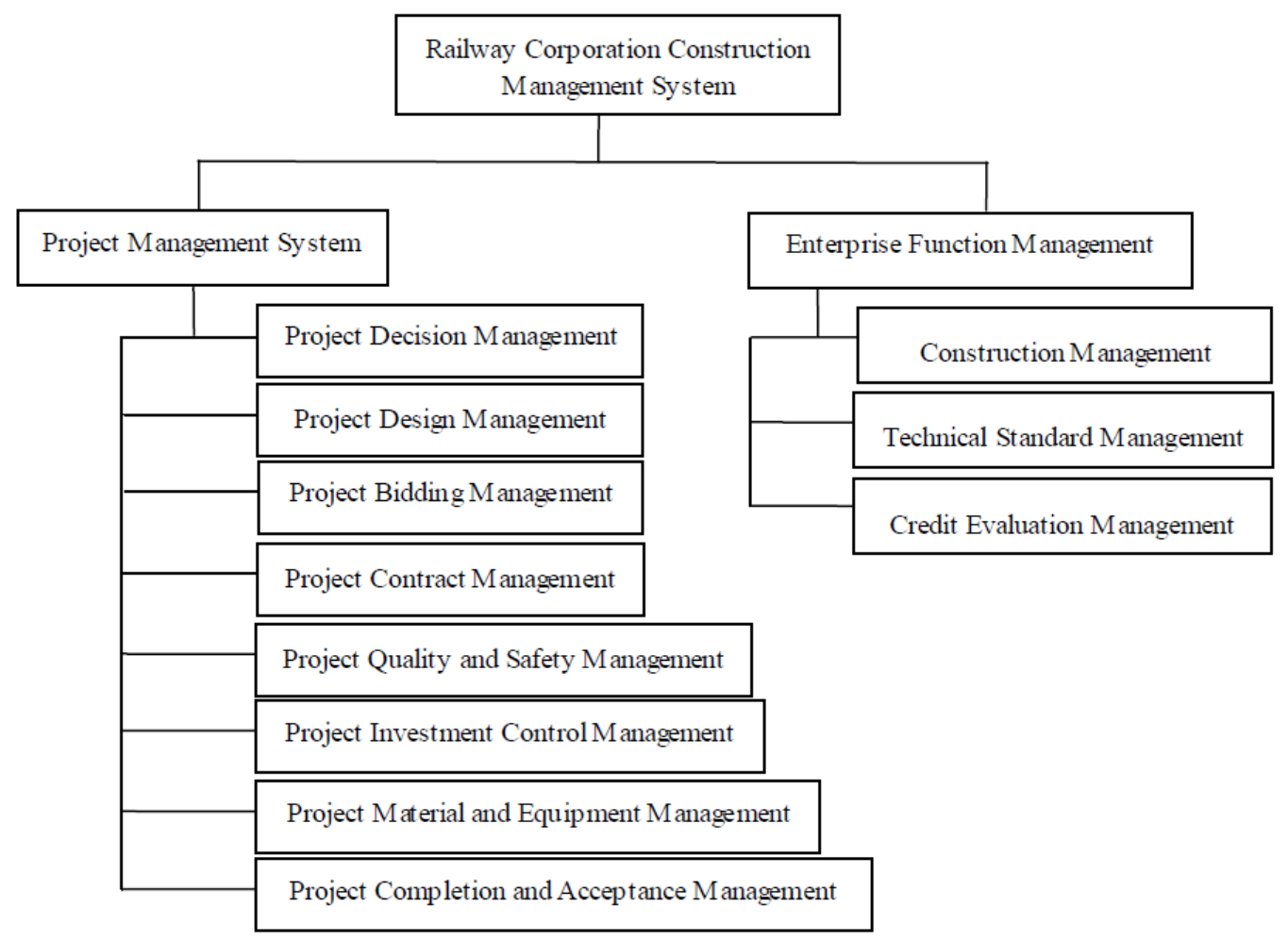

Fig.3 Railway Corporation construction management system schematic 
It should be noted that the railway corporation internal rules and regulations adjustment will have a direct effect on construction management agency of all proposed railway construction projects. All construction management agencies will execute the new rules and regulations. Therefore, during the transition period, the contractors' team is likely to face some degree of unsuitable situation, because before they only observe the original Ministry of Railways's request, and now need to accept National Railway Administration and Railway Corporation dual management. On the other side, this also set a higher request to the National Railway Administration's establishment of rules and regulations work. The new rules and regulations should consider policy coherence and consistency, and a gradual transition from the original period of Railways.

\section{Several problems of railway construction management transformation}

Abolishment of the original Ministry of Railways, establishment of the National Railway Administration and China Railway Corporation, which represent a new era of railway construction management. A typical feature is that identity of railway construction management unit is transforming and differentiation. This change affects not only institutional environment and market rules of the railway construction management, will also affect its management style.

\section{Government Supervision departments should strengthen law enforcement responsibility and duty}

For the National Railways take purely governmental functions, it must change amplitude and behavior compared with the original period of Railway. On the one hand, National Railways Administration should clear the "legal authority" basic principles, namely "For the law without authorization". It must strictly follow the rule of law and legal procedure, consciously accept supervision and legal liability, overcome the rule of man and the power of thinking and recognize the supreme authority of law and the limitation of public authority functions.

On the other hand, National Railways Administration need strengthen its awareness of duties, carry on the law enforcement inspection in accordance with laws, regulations and mandatory standards. The inspection should highlight randomness and comprehensiveness, through investigated violations to regulate the market and achieve the purpose of reward and punishment. Especially, the supervision department is not the main market responsible party, does not bear direct responsibility for the quality and safety. It should get rid of the phenomenon of dislocation, give back quality and safety responsibilities to the market firms.

\section{Railway construction project owners should strengthen market awareness and contract consciousness}

With the railway investment and financing system reformation, diversity of investors in railway construction projects will become more common. Railway construction project owners will gradually become different joint-stock companies or project corperation. Whether China Railway Corporation or diversified project corporations, and even local government railway companies, must get rid of Administrative and instructional management stytle.

Of course , China Railway Corporation will face this challenge first. On the one hand, because the industry regulation and market regulation is not a business function, so China Railway Corporation should remove administrative thinking in the development of business rules and regulations. It can no longer direct instructions and requirements for enterprises who are not affiliated with the Railway Corporation, including the design firms, construction firms, etc. On the other hand, it can enhance market awareness by means of contract, through the contract to reflect the requirements of the owner within the scope of the laws and regulations. Also through the contract performance and breach of contract records to strengthen the participation units of rewards and punishments.

\section{Railway construction project management agencies should strengthen governance awareness}

Under the new situation, the management philosophy of railway construction project should take 
the transformation from management to governance .Management tends to emphasize the unity of the management body,its guiding principle is control principle. Managers are often based on rules or regulations, emphasizing passive obedience state by managers and achieving its goals in accordance with the requirements of managers. Governance is the way that refers to the sum of the many organizations and institutions to manage their common things. It is a process that continually adjust different conflicts and interests and take joint action. In a word, governance emphasizes the coordination principle.

After the Railway construction project management agency status change, it should gradually change mandatory administrative management thinking. Based on policies, regulations and contracts, management agency should more use governance tools and governance thinking, improve communication and coordination ability, foster respect, equality and consultation attitude. Thus, it can solve the railway construction land acquisition, construction conflicts and other issues, and further enhance the flexibility of management.

\section{Conclusion}

At present, China railway construction has entered the transition period. Typical features include two aspects, both the change of original Railways project owner' dual identity and the adjustment of railway construction regulations and rules. In the short term, this will require that the government regulators and the railway construction project managers to define their respective responsibilities and obligations. In the long term, after Government-corporation separation, more transformation will focus on railway investment and financing reform, market adjustment of supply and demand. Whatever, during the transition period, all railway construction firms need to strengthens awareness of the law. On the basis of the rule of law, to shape a fair and competitive market environment in order to stimulate the creativity of market players, and comprehensively promote the level of railway construction management.

\section{Acknowledgement}

Hebei province science and technology project "Research on Governance Strategy of Construction Project Stakeholders", Number: 14457668D.

\section{References}

[1] Official Approval about Organization of China Railway Corporation by State Government [S] No.47 of Official Letter State Government (2013), 2013.3.14.

[2] Liu Fang, Ding Rong-gui, Research on the Dynamic Governance Relationships among Project Stakeholders. [D] University of Shandong, 2012.

[3] Yang Ya-wei, Research on System-engineering-based Closed Loop Management Mode for Railway Engineering Project [J].Journal of Railway Engineering Society, 2011(5):106-109.

[4] Han Tong-yin, Wang Shu-yu, Lei Shu-hua, Review and Prospects for Management Reform of Railway Construction [J], Journal of Railway Engineering Society, 2007(1):65-70. 